
異なる電子線エネルギー混合照射の線量分布の検討 : 実現可能性試験

論文受付

2019 年 4 月 25 日

論文受理

2019 年 11 月 14 日

Code No. 430
下郷智弘 ${ }^{1} \quad$ 奥平訓康 ${ }^{2}$

\author{
1 岐阜医療科学大学保健科学部放射線技術学科 \\ 2 名古屋大学医学部附属病院放射線部
}

\section{緒 言}

外部放射線照射療法では，ケロイド，皮膚がん，胸 壁リンパ節転移などのような表在性疾患に対して電子 線照射が行われることがある ${ }^{1 \sim 31}$ ，治療に使用される 電子線のエネルギーは, 腫瘍の厚さと最大深さによっ て決定される。放射線治療計画では, 腫瘍周囲の治療 体積が等線量曲線の $80 \%$ から 90\%線量範囲内に収ま るように電子ビームのエネルギーが選択される ${ }^{4 \sim 7)}$. 電子線ビームの深さ方向の分布は, 低い表面線量と線 量最大深以降での線量の急激な減少(fall-off)をもつ特 徵的な線量分布であるために，深さ方向の治療有効領 域幅は非常に狭く，体積の大きい腫瘍では，標的体積 全体に処方線量を投与することが困難な場合がある.

過去の研究者ら ${ }^{8 \sim 10)}$ は, 電子線ビームと X 線ビーム からの照射を混合することによって線量分布の改善を 試みている。特に, 近年では, 電子線ビームが X 線強 度変調放射線治療における線量分布を改善するために 使用されることがある ${ }^{11,12)}$ 。これらの方法では，X 線

\title{
Dose Distribution Combinations of Different Electron Beam Energy for Treatment Region Expansion in High-energy Electron Beam Radiation Therapy: A Feasibility Study
}

\author{
Tomohiro Shimozato $^{1 *}$ and Kuniyasu Okudaira ${ }^{2}$ \\ ${ }^{1}$ Department of Radiological Technology, Faculty of Health Science, Gifu University of Medical Science \\ ${ }^{2}$ Department of Radiotherapy, Nagoya University Hospital
}

Received April 25, 2019; Revision accepted November 14, 2019

Code No. 430

\begin{abstract}
Summary
Introduction: External electron beams have excellent distributions in treatment for superficial tumors while suppressing influence deeper normal tissue. However, the skin surface cannot be given a sufficient dose due to the build-up effect. In this study, we have investigated the combination of electron beams to expand the treatment region by keeping the dose gradient beyond $\mathrm{d}_{\max }$. Materials and Methods: The percentage depth doses of different electron beams were superimposed on a spreadsheet to determine the combinations of electron beams so that the treatment range was maximized. Based on the obtained weight for electron beams, dose distributions were calculated using a treatment planning system and examined for potential clinical application. Results: With the combination of $4 \mathrm{MeV}$ and $9 \mathrm{MeV}$ electron beams, the $90 \%$ treatment range in the depth direction increased by 8.0 $\mathrm{mm}$, and with $4 \mathrm{MeV}$ and $12 \mathrm{MeV}$ beams, it increased by $4.0 \mathrm{~mm}$, with the same maximum dose depth and halfdose depth of the absorbed dose. The dose calculations were performed using the treatment planning system yielded similar results with a matching degree of $\pm 1.5 \%$. Conclusions: Although the influences of low monitor unit values and daily output differences remain to be considered, the results suggest that the proposed approach can be clinically applied to expand treatment regions easily.
\end{abstract}

Keywords: electron radiotherapy, mixed electron beam, treatment range

*Corresponding author 
照射だけでは十分な線量を標的体積に与えることがで きない場合に，線量を補うために電子線が追加されて いる，また，電子線のエネルギーや照射位置等を調整 することによる電子線強度変調照射も研究されてい る $^{13 \sim 15)}$.

本研究では, 放射線治療計画装置 (treatment planning system: TPS) に登録されている基準データ(ビー ムデータ)を用いて，市販のスプレッドシート上で電 子線の特徴的な深部線量分布特性を維持しながら, 深 さ方向の治療有効領域幅を拡大するための各エネル ギーの最適な組み合わせを検討した。 また，その組み 合わせにおいて, 電子線モンテカルロ (eMC)アルゴリ ズムを搭載したTPSを用いて線量計算を行い, 計算 された線量分布の臨床応用の可能性について検討し た. eMCアルゴリズムの線量計算の正確性について は，過去の論文において，十分な計算精度が実証され ている ${ }^{16 \sim 18)}$. これらの報告では, 一つの公称エネル ギーを用いた従来の電子線治療では, TPS は対応する 測定值に近い計算線量を提供することができると報告 されている。この研究では, 混合電子ビームによって 提供される線量を計算するためにTPSを利用し，深 さと横方向の広がりを評価した。

\section{1. 方 法}

\section{1-1 深部量百分率の測定}

放射線治療装置 Clinac iX (Varian Medical Systems. Palo Alto, CA, USA)によって放出された公称エネル ギー4，6，9，12，および $16 \mathrm{MeV}$ の電子線ビームを使 用して, 水ファントムのビーム中心軸上の深部電離量 百分率 $(\mathrm{PDI})$ を測定した。測定には, 解析ソフトウェ ア MEPHYSTO $\mathrm{mc}^{2}$ (PTW Freiburg, Freiburg, Baden-Württemberg, Germany)によって制御される 三次元水ファントム (MP3 Phantom タンク, PTW Freiburg)を使用した。 PDI 值は，-300 V の電圧が印 加された平行平板形電離箱線量計 (Advanced Markus TN34045, PTW Freiburg)で測定した.これらの值 は，極性効果のみについて補正されている。また，ス キャンデータを, AAPM TG106 ${ }^{19)}$ で提案されている 方法を参考に測定した。深さ方向の測定間隔は 1.0 $\mathrm{mm}$ で行った。照射野は，線源ファントム表面間距離 (SSD) で照射アプリケータ (A10)の射出口にカットア ウトブロックによる正方形照射野 $10 \times 10 \mathrm{~cm}^{2}$ のサイ ズを成型したものを使用した。二次コリメータサイズ は，製造業者による推奨值を用い，4，6，9 MeVの電 子ビームエネルギーに対して $20 \times 20 \mathrm{~cm}^{2}$ ，および 12 , $16 \mathrm{MeV}$ に対して $14 \times 14 \mathrm{~cm}^{2}$ とした. PDI 值は,
AAPM TG25 20$)$ に詳述されているプロトコルに従って 深部量百分率 $(\mathrm{PDD})$ に MEPHYSTO 上で変換された。

また，後述する最適な電子線エネルギーの組み合わ せで, 水中の各深さにおける電離量を測定した。電離 量測定值は, 3 回から 5 回の測定值の平均值とした。 標準計測法 ${ }^{21)}$ に示されるように, 吸収線量を求める際 の擾乱係数として文献 ${ }^{22)}$ のデー夕を使用し, 各エネル ギーにおける深さごとの水/空気平均制限質量衝突阻 止能比 (以下, 阻止能比)を乗じることによって吸収線 量の算出を求め, 合計線量の最大となる深さで正規化 し, PDD曲線を作成した。一例として, $4 \mathrm{MeV}$ と 9 $\mathrm{MeV}$ の線量比が $9: 91$ の混合照射が最適と判断され た場合，まず, $4 \mathrm{MeV}$ 電子線を $9 \mathrm{MU}$ (monitor unit 設 定值) 照射し, 温度気圧補正された電離量測定值に水 吸収線量校正定数, 深さに対応する擾乱補正係数と阻 止能比を乗じ吸収線量を求めた。次に, $9 \mathrm{MeV}$ 電子線 を $91 \mathrm{MU}$ 照射し, 同様に擾乱補正係数と阻止能比を 乗じて吸収線量を求め足し合わせることで, 各深さの 吸収線量值とした。平行平板型電離箱線量計は, 詳細 なデータの存在する NACP-02 (Ser. No. 20456 PTW Freiburg) を使用した。電位計は, PTW UNIDOS webline 10023 (Ser. No. 2031 PTW Freiburg)を使用し た。印加電圧は, $-200 \mathrm{~V}$ で測定を行った。測定間隔 は $2 \mathrm{~mm}$ とし, 極性効果補正およびイオン再結合補正 は施さなかった。

\section{1-2 異なるエネルギーの電子線深部量分布曲線の組 み合わせ}

混合された PDD は，9，12，および $16 \mathrm{MeV}$ のいず れかの単一エネルギー電子線ビームの PDD と, より 低いエネルギーを持つ電子線ビームの PDD との組み 合わせを検討した. $9 \mathrm{MeV}$ と混合するエネルギーは, $4 \mathrm{MeV}$ または $6 \mathrm{MeV}$ をいずれか, または両方を組み 合わせた。 $12 \mathrm{MeV}$ のPD は，4，6，または $9 \mathrm{MeV}$ のビームの PDD，またはそれら複数のエネルギーの 組み合わせで混合された。 そして $16 \mathrm{MeV}$ の PD

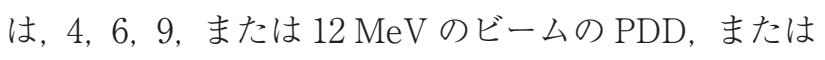
それら複数のエネルギーの組み合わせで混合された。 そして, 異なる電子ビームの組み合わせについて, 深 さ方向における表面から 80，90，95，98\%線量深まで を治療領域幅 (treatment region width: TR) と定義し サイズおよび均一性を調べた。均一性は, TR 範囲内 の線量の標準偏差 (standard deviation: SD) で評価し た。重み付けは, 市販のスプレッドシートソフトウェ ア Excel 2016(Microsoft, Redmond, WA, USA)を使用 して, 整数值のモニタ単位数 (MU)によって決定した. 
Table 1 MU values, $80,90,95,98 \% \mathrm{TR}, \mathrm{d}_{\max }, \mathrm{R}_{50}$, and surface dose for each energy combination with a nominal 9 MeV electron beam

\begin{tabular}{|c|c|c|c|c|c|c|c|c|c|}
\hline Combination of energies & Energy & MU & $\begin{array}{c}80 \% \mathrm{TR} \\
(\mathrm{mm})\end{array}$ & $\begin{array}{c}90 \% \mathrm{TR} \\
(\mathrm{mm})\end{array}$ & $\begin{array}{c}95 \% \mathrm{TR} \\
(\mathrm{mm})\end{array}$ & $\begin{array}{c}98 \% \mathrm{TR} \\
(\mathrm{mm})\end{array}$ & $\begin{array}{l}\mathrm{d}_{\max } \\
(\mathrm{mm})\end{array}$ & $\begin{array}{c}\mathrm{R}_{50} \\
(\mathrm{~mm})\end{array}$ & $\begin{array}{c}\text { Surface dose } \\
(\%)\end{array}$ \\
\hline $9 \mathrm{MeV}$ & 9 & 100 & $\begin{array}{c}30.0 \\
(5.87)\end{array}$ & $\begin{array}{c}18.5 \\
(3.12)\end{array}$ & $\begin{array}{c}11.5 \\
(1.50)\end{array}$ & $\begin{array}{c}7.0 \\
(0.64)\end{array}$ & 21.0 & 35.7 & 82.5 \\
\hline $4 \mathrm{MeV}+9 \mathrm{MeV}$ & $\begin{array}{l}4 \\
9\end{array}$ & $\begin{array}{c}9 \\
91\end{array}$ & $\begin{array}{c}30.0 \\
(4.54)\end{array}$ & $\begin{array}{c}26.5 \\
(2.90)\end{array}$ & $\begin{array}{c}21.0 \\
(1.20)\end{array}$ & $\begin{array}{c}17.0 \\
(0.55)\end{array}$ & 21.0 & 35.7 & 89.9 \\
\hline $4 \mathrm{MeV}+6 \mathrm{MeV}+9 \mathrm{MeV}$ & $\begin{array}{l}4 \\
6 \\
9\end{array}$ & $\begin{array}{c}8 \\
1 \\
91\end{array}$ & $\begin{array}{c}30.0 \\
(4.70)\end{array}$ & $\begin{array}{c}25.5 \\
(2.77)\end{array}$ & $\begin{array}{c}20.5 \\
(1.24)\end{array}$ & $\begin{array}{c}15.5 \\
(0.47)\end{array}$ & 21.0 & 35.6 & 89.3 \\
\hline $6 \mathrm{MeV}+9 \mathrm{MeV}$ & $\begin{array}{l}6 \\
9\end{array}$ & $\begin{array}{c}1 \\
99\end{array}$ & $\begin{array}{c}30.0 \\
(5.88)\end{array}$ & $\begin{array}{c}19.0 \\
(3.20)\end{array}$ & $\begin{array}{c}12.0 \\
(1.58)\end{array}$ & $\begin{array}{c}7.0 \\
(0.64)\end{array}$ & 21.0 & 35.6 & 82.7 \\
\hline
\end{tabular}

The numbers in parentheses indicate the standard deviations of the doses within the treatment regions.

Table 2 MU values, $80,90,95,98 \%$ TR, $d_{\max }, R_{50}$ and surface dose for each energy combination with a nominal $12 \mathrm{MeV}$ electron beam

\begin{tabular}{|c|c|c|c|c|c|c|c|c|c|}
\hline Combination of energies & Energy & MU & $\begin{array}{c}80 \% \mathrm{TR} \\
(\mathrm{mm})\end{array}$ & $\begin{array}{c}90 \% \mathrm{TR} \\
(\mathrm{mm})\end{array}$ & $\begin{array}{c}95 \% \mathrm{TR} \\
(\mathrm{mm})\end{array}$ & $\begin{array}{c}98 \% \mathrm{TR} \\
(\mathrm{mm})\end{array}$ & $\begin{array}{l}\mathrm{d}_{\max } \\
(\mathrm{mm})\end{array}$ & $\begin{array}{c}\mathrm{R}_{50} \\
(\mathrm{~mm})\end{array}$ & $\begin{array}{c}\text { Surface dose } \\
(\%)\end{array}$ \\
\hline $12 \mathrm{MeV}$ & 12 & 100 & $\begin{array}{c}42.5 \\
(4.53)\end{array}$ & $\begin{array}{l}35.0 \\
(2.97)\end{array}$ & $\begin{array}{c}22.5 \\
(1.53)\end{array}$ & $\begin{array}{c}12.5 \\
(0.60)\end{array}$ & 29.0 & 50.3 & 87.7 \\
\hline $4 \mathrm{MeV}+12 \mathrm{MeV}$ & $\begin{array}{c}4 \\
12\end{array}$ & $\begin{array}{c}6 \\
94\end{array}$ & $\begin{array}{c}42.5 \\
(4.01)\end{array}$ & $\begin{array}{l}39.0 \\
(2.29)\end{array}$ & $\begin{array}{c}32.5 \\
(1.19)\end{array}$ & $\begin{array}{l}27.0 \\
(0.98)\end{array}$ & 29.0 & 50.3 & 92.5 \\
\hline $6 \mathrm{MeV}+12 \mathrm{MeV}$ & $\begin{array}{c}6 \\
12\end{array}$ & $\begin{array}{c}4 \\
96\end{array}$ & $\begin{array}{c}42.5 \\
(4.61)\end{array}$ & $\begin{array}{c}37.5 \\
(2.98)\end{array}$ & $\begin{array}{c}28.0 \\
(1.48)\end{array}$ & $\begin{array}{c}18.5 \\
(0.56)\end{array}$ & 23.0 & 50.1 & 89.9 \\
\hline $4 \mathrm{MeV}+6 \mathrm{MeV}+12 \mathrm{MeV}$ & $\begin{array}{c}4 \\
6 \\
12\end{array}$ & $\begin{array}{l}5 \\
1 \\
94\end{array}$ & $\begin{array}{c}42.5 \\
(4.11)\end{array}$ & $\begin{array}{c}39.0 \\
(2.37)\end{array}$ & $\begin{array}{c}32.5 \\
(1.15)\end{array}$ & $\begin{array}{l}26.5 \\
(0.74)\end{array}$ & 27.5 & 50.2 & 92.4 \\
\hline $4 \mathrm{MeV}+9 \mathrm{MeV}+12 \mathrm{MeV}$ & $\begin{array}{c}4 \\
9 \\
12\end{array}$ & $\begin{array}{c}6 \\
1 \\
93\end{array}$ & $\begin{array}{c}42.5 \\
(4.19)\end{array}$ & $\begin{array}{c}39.0 \\
(2.38)\end{array}$ & $\begin{array}{c}32.5 \\
(1.20)\end{array}$ & $\begin{array}{l}27.0 \\
(0.93)\end{array}$ & 28.0 & 50.2 & 92.6 \\
\hline $6 \mathrm{MeV}+9 \mathrm{MeV}+12 \mathrm{MeV}$ & $\begin{array}{c}6 \\
9 \\
12\end{array}$ & $\begin{array}{c}3 \\
1 \\
96\end{array}$ & $\begin{array}{c}42.5 \\
(4.69)\end{array}$ & $\begin{array}{c}36.5 \\
(2.90)\end{array}$ & $\begin{array}{c}27.0 \\
(1.48)\end{array}$ & $\begin{array}{l}18.0 \\
(0.61)\end{array}$ & 25.0 & 50.1 & 89.5 \\
\hline $4 \mathrm{MeV}+6 \mathrm{MeV}+9 \mathrm{MeV}+12 \mathrm{MeV}$ & $\begin{array}{c}4 \\
6 \\
9 \\
12\end{array}$ & $\begin{array}{c}5 \\
2 \\
1 \\
92\end{array}$ & $\begin{array}{c}42.5 \\
(4.46)\end{array}$ & $\begin{array}{c}38.5 \\
(2.37)\end{array}$ & $\begin{array}{c}32.5 \\
(1.18)\end{array}$ & $\begin{array}{l}27.5 \\
(0.57)\end{array}$ & 26.0 & 50.1 & 93.1 \\
\hline
\end{tabular}

The numbers in parentheses indicate the standard deviations of the dose within the treatment regions.

電子線エネルギーの組み合わせごとに，グラフを視覚 的に確認しながら, 元の曲線の線量最大深 $\left(\mathrm{d}_{\max }\right)$ 拈よ び線量半価深 $\left(\mathrm{R}_{50}\right)$ への変化を最小にする組み合わせ を用いて, 混合線量の重み付け割合を調査した。各電 子エネルギーについて, $1 \mathrm{MU}$ 当たりの吸収線量は水 中に㧍ける PDD の $\mathrm{d}_{\max }$ で $1 \mathrm{cGy}$ に調整されている.

\section{1-3ｅMC アルゴリズムを使用した計算}

上記のセクション 1-2で説明したように決定された 重み付けに基づいて, 放射線治療計画装置 Eclipse バージョン 13.6(Varian Medical Systems)に搭載され ている線量計算アルゴリズム $\mathrm{eMC}$ バージョン 13 を 使用して, 線量分布を各エネルギーについて計算し た，計算グリッドの大きさは $1 \times 1 \times 1 \mathrm{~mm}^{3}$ である. 統 計誤差は $1 \%$ として計算した。平滑化処理はオフにし
た。そして，eMCアルゴリズムを使用して計算され た異なる電子線の組み合わせの PDD を，上記のセク ション 1-2で述べたExcel で計算された混合の PDD と比較した。

\section{2. 結 果}

\section{2-1 混合 $P D D$}

Table 1〜3に，それぞれ 9, $12,16 \mathrm{MeV}$ の電子線を 主体とした組み合わせの MU 值，80，90，95，98\%の TR および $\mathrm{d}_{\max }, \mathrm{R}_{50}$ ，表面線量を示す，表面線量は ICRU Report 35 ${ }^{23)}$ によって定義されている深さ 0.5 $\mathrm{mm}$ に扔ける線量とした。また各 TR 值に記載されて いる括弧内の数值は，均一性を示している。電子線工 ネルギーの組み合わせは，TRをより大きくし， $\mathrm{d}_{\max }$ および $\mathrm{R}_{50}$ の変化を少なくするように決定されたの 
Table 3 MU values, $80,90,95,98 \% \mathrm{TR}, \mathrm{d}_{\max }, \mathrm{R}_{50}$ and surface dose for each energy combination with a nominal $16 \mathrm{MeV}$ electron beam

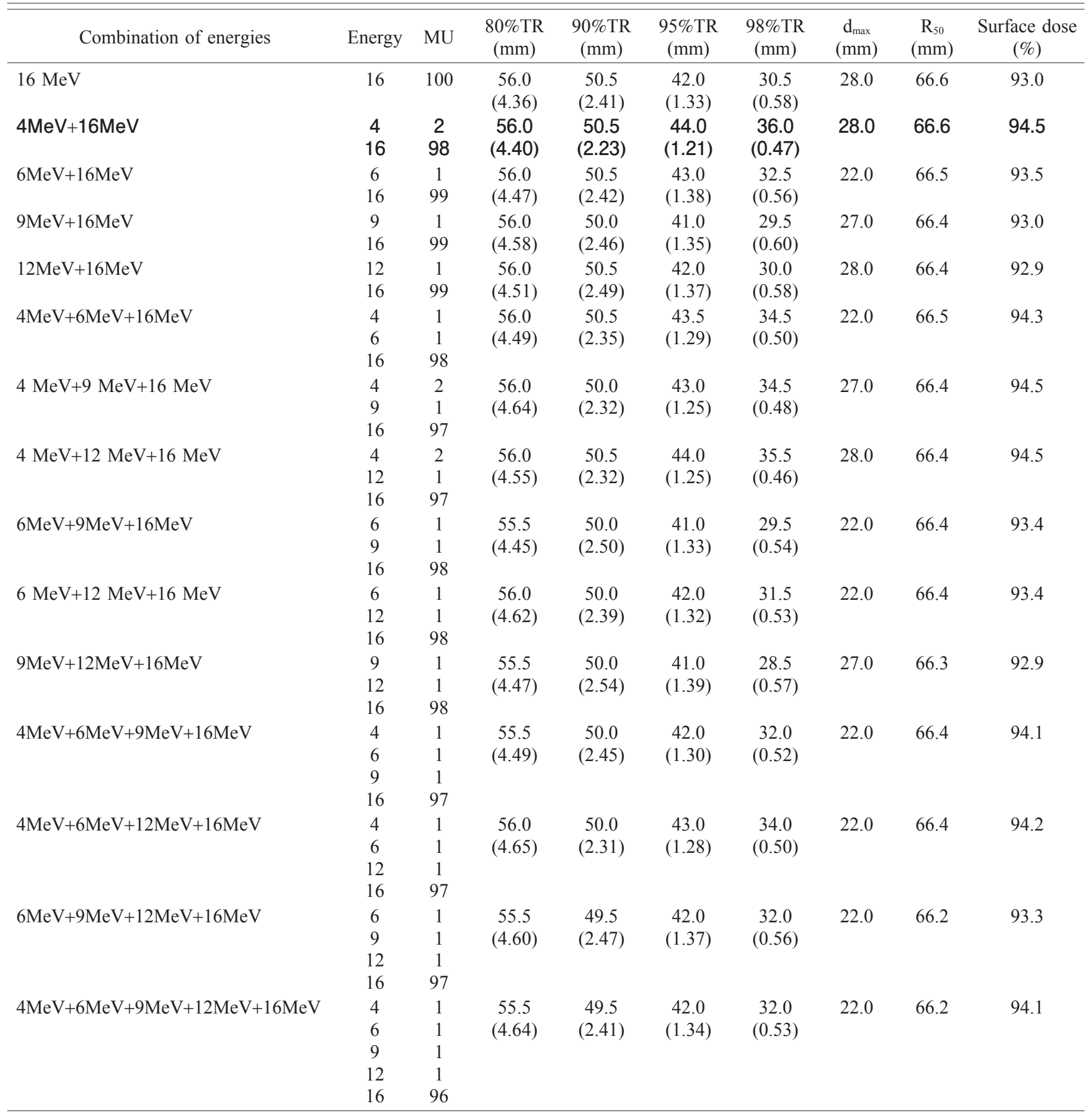

The numbers in parentheses indicate the standard deviations of the doses within the treatment regions.

で，電子線ビームの $\mathrm{d}_{\max }$ より深い位置における減衰特 性は維持された。

混合 PDDの例として, Fig. 1 に $9 \mathrm{MeV}$ の電子線を 主体とした組み合わせとして, $4 \mathrm{MeV}$ と $9 \mathrm{MeV}$ の電 子ビームを組み合わせたPDD を示す. Table 1 に示 すように, 混合 PDDの表面線量は公称エネルギー $9 \mathrm{MeV}$ の電子線ビームの線量と比較して $82.5 \%$ から 89.9\%に増加した。また，90，95，98\%のTRは, 単一 の電子線エネルギーで得られたものと比較して，それ
ぞれ， 8.0, 9.5, $10.0 \mathrm{~mm}$ 拡大した.

同様に, $9 \mathrm{MeV}$ の電子線を主体とした組み合わせと して, Fig. 2 に $6 \mathrm{MeV}$ と $9 \mathrm{MeV}$ を $1: 99$ および 10 : 90 で組み合わせたPDD を示す。1：99 で組み合わせ た場合， $\mathrm{d}_{\max }$ 掞よび $\mathrm{R}_{50}$ は公称エネルギー $9 \mathrm{MeV}$ の電 子線の值と $0.1 \mathrm{~mm}$ 以内で一致した。一方, 10:90の 組み合わせでは，減衰領域の傾きは緩やかになり， $\mathrm{d}_{\max }$ は浅くなった。

更に, $9 \mathrm{MeV}$ の電子線を主体とした組み合わせとし 


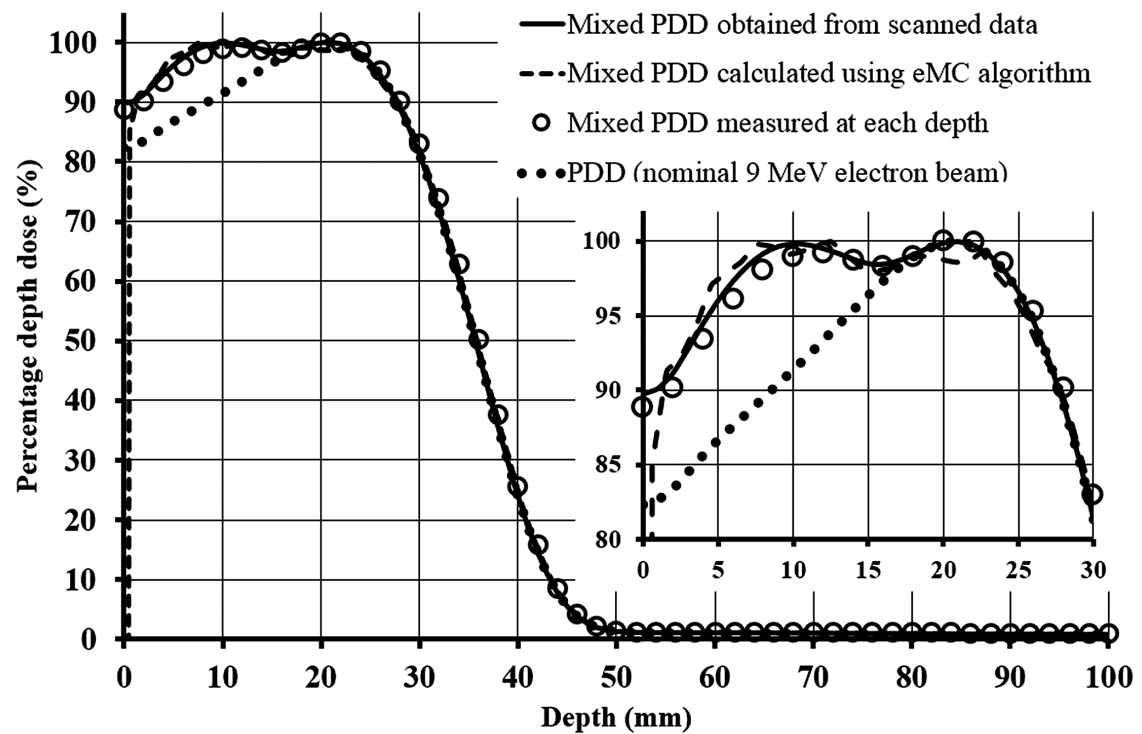

Fig. 1 Mixed PDD from the scanned data (solid line) and distribution calculated using the eMC algorithm (dashed line) with weighting 9:91 from the $4 \mathrm{MeV}$ and $9 \mathrm{MeV}$ electron beams.

The dotted line represents the measured PDDs for the nominal $9 \mathrm{MeV}$ electron beams.

The circles represent the measured PDDs obtained from absorbed dose at each depth.

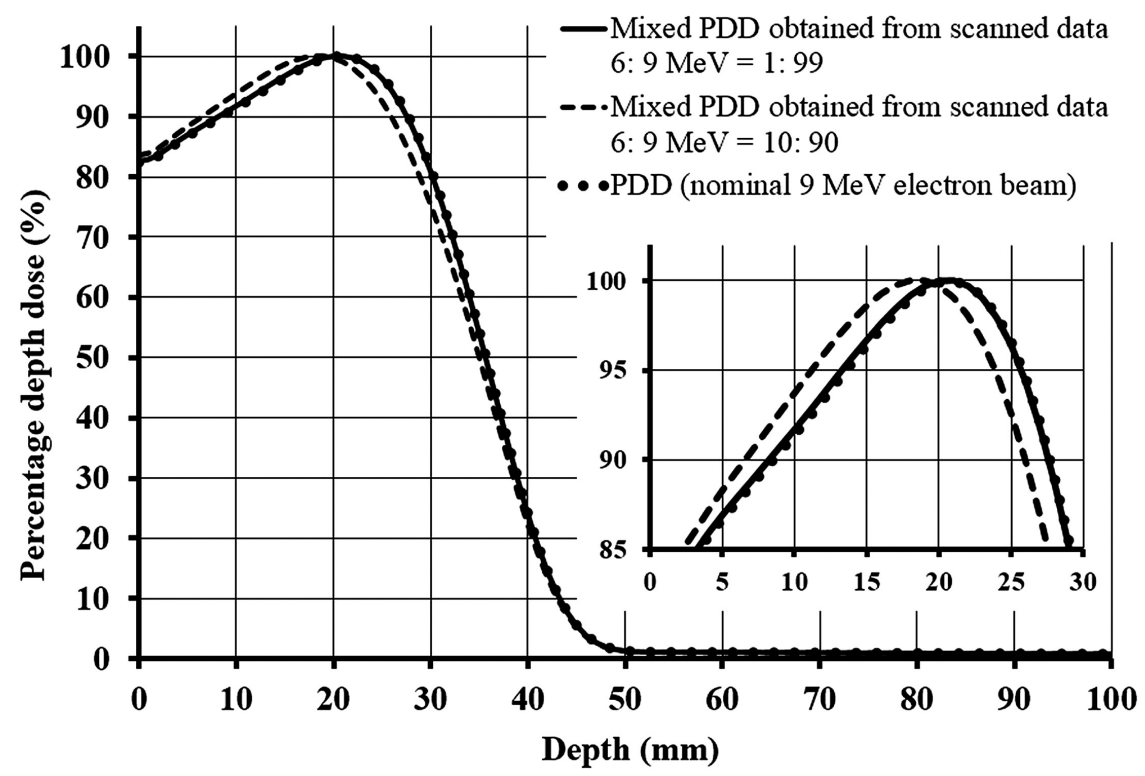

Fig. 2 Mixed PDD with weighting 1:99 from the scanned data (solid line) and mixed PDD with weighting 10:90 (dashed line) for the 6 $\mathrm{MeV}$ and $9 \mathrm{MeV}$ electron beams.

The dotted line represents the measured PDD for the nominal $9 \mathrm{MeV}$ electron beam.

て, Fig. 3 に 4, 6, $9 \mathrm{MeV}$ のビームを $8: 1: 91$ および $9: 1 ： 90$ で組み合わせた PDD を示す。この組み合わ せでは，低エネルギーの $4 \mathrm{MeV}$ のビームを $1 \mathrm{MU}$ 増 量すると分布に変化が現れ, Table 1 に示された線量 (MU 值)の組み合わせを選択した。他の組み合わせに ついても同様に検討し， $4 \mathrm{MeV}$ と $9 \mathrm{MeV}$ の組み合わ せで，重み付けを 9：91 とした場合が最適であると判 断した.
次に, $12 \mathrm{MeV}$ の電子線を主体とした組み合わせと して, Fig. 4 に $4 \mathrm{MeV}$ と $12 \mathrm{MeV}$ のビームを組み合わ せたPDD を示す。この組み合わせでは，80\% TRの 值は, いずれも変化がなかった. $4 \mathrm{MeV}$ と $12 \mathrm{MeV}$ ビームの組み合わせについては, Table 2 に示される ように，90，95，98\% TRがそれぞれ4.0，10.0，14.5 $\mathrm{mm}$ 拡大されており, 一方 $\mathrm{d}_{\max }$ および $\mathrm{R}_{50}$ は変化しな いままであった。 


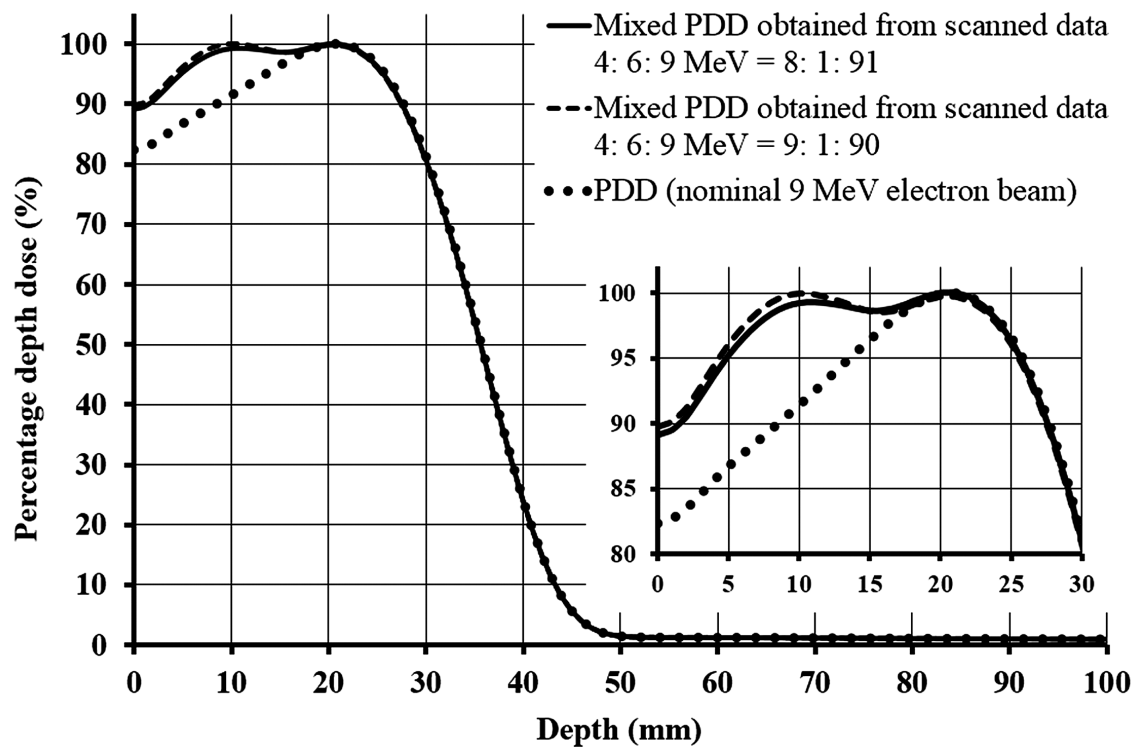

Fig. 3 Mixed PDD with weighting 8:1:91 from the scanned data (solid line) and mixed PDD with weighting 9:1:90 (dashed line) for the 4, 6 , and $9 \mathrm{MeV}$ electron beams.

The dotted line represents the measured PDD for the nominal $9 \mathrm{MeV}$ electron beam.

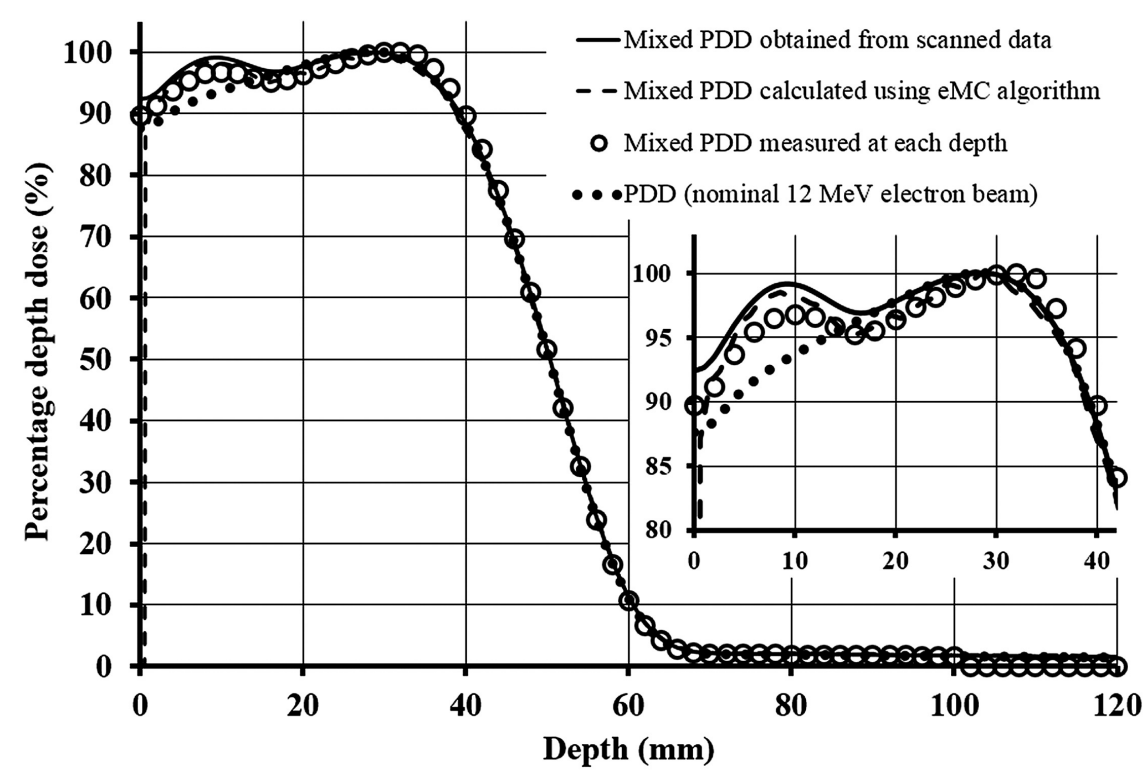

Fig. 4 Mixed PDD from the scanned data (solid line) and the distribution calculated using the eMC algorithm (dashed line) with weighting 6:94 from the $4 \mathrm{MeV}$ and $12 \mathrm{MeV}$ electron beams.

The dotted line represents the measured PDD for the nominal $12 \mathrm{MeV}$ electron beams.

The circles represent the measured PDDs obtained from absorbed dose at each depth.

同様に, $12 \mathrm{MeV}$ の電子線を主体とした組み合わせ として, Fig. 5 に示す $6 \mathrm{MeV}$ と $12 \mathrm{MeV}$ を 4:96 およ び 6:94で組み合わせたPDD では, $6 \mathrm{MeV}$ のビーム の重量が増加するにつれて, 混合 PDD の $\mathrm{d}_{\max }$ は浅く なった，更に，TRの拡大率は少なく， $\mathrm{R}_{50}$ は浅くなっ た。ほかにも可能な組み合わせについて検討し, $4 \mathrm{MeV}$ と $12 \mathrm{MeV}$ の組み合わせで, 重み付けが 6:94 の場合が最適であると判断した。

最後に, $16 \mathrm{MeV}$ の電子線を主体とした組み合わせ
として, Fig. 6 に $4 \mathrm{MeV}$ と $16 \mathrm{MeV}$ のビームを組み合 わせたPDD を示す。この組み合わせは, Table 3 に 示すように，95，98\%の TR をそれぞれ 2.0，5.5 mm 拡大したが, $\mathrm{d}_{\max }$ 㧍よび $\mathrm{R}_{50}$ に変化はみられなかった。 ほかにも可能な組み合わせについて検討し, $4 \mathrm{MeV}$ と $16 \mathrm{MeV}$ の組み合わせで，重み付けが 2:98の場合が 最適であると判断した。最適と判断されたエネルギー の組み合わせについて，各深さでエネルギーを変化さ せて測定し得られたPDD を, Fig. 1，4，6に丸印でそ 


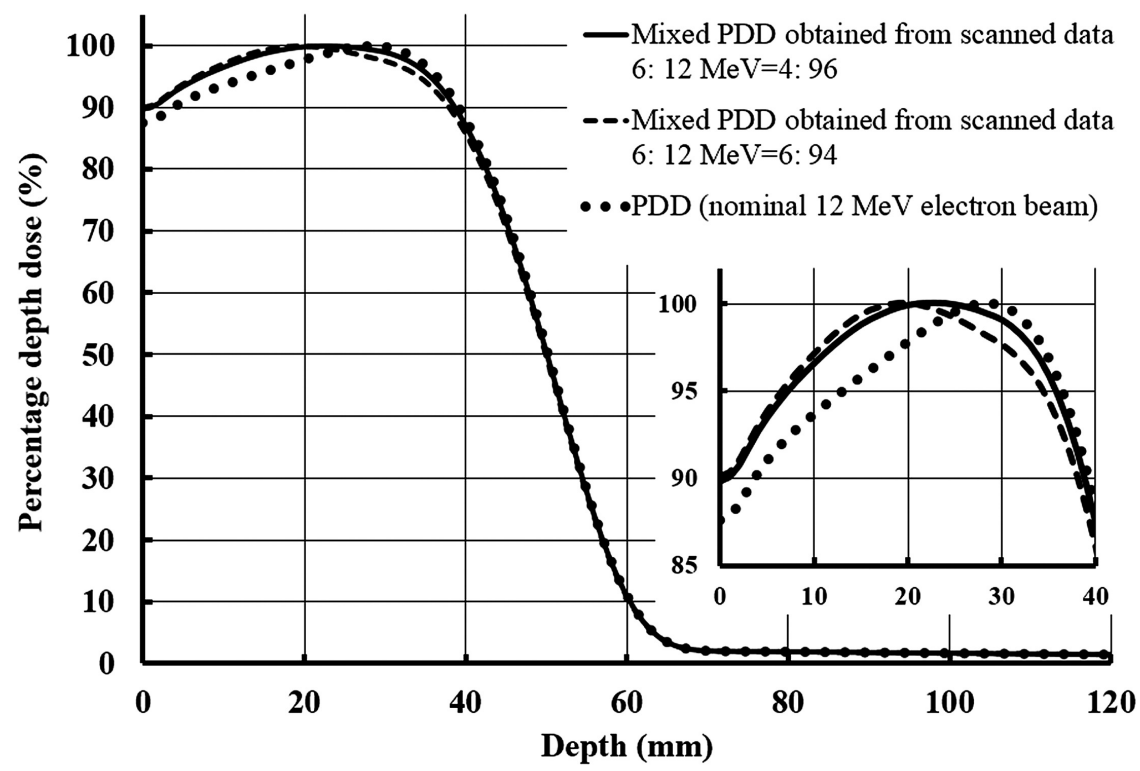

Fig. 5 Mixed PDD with weighting 4:96 from the scanned data (solid line) and mixed PDD with weighting 6:94 (dashed line) for the $6 \mathrm{MeV}$ and $12 \mathrm{MeV}$ electron beams.

The dotted line represents the measured PDD for the nominal $12 \mathrm{MeV}$ electron beams.

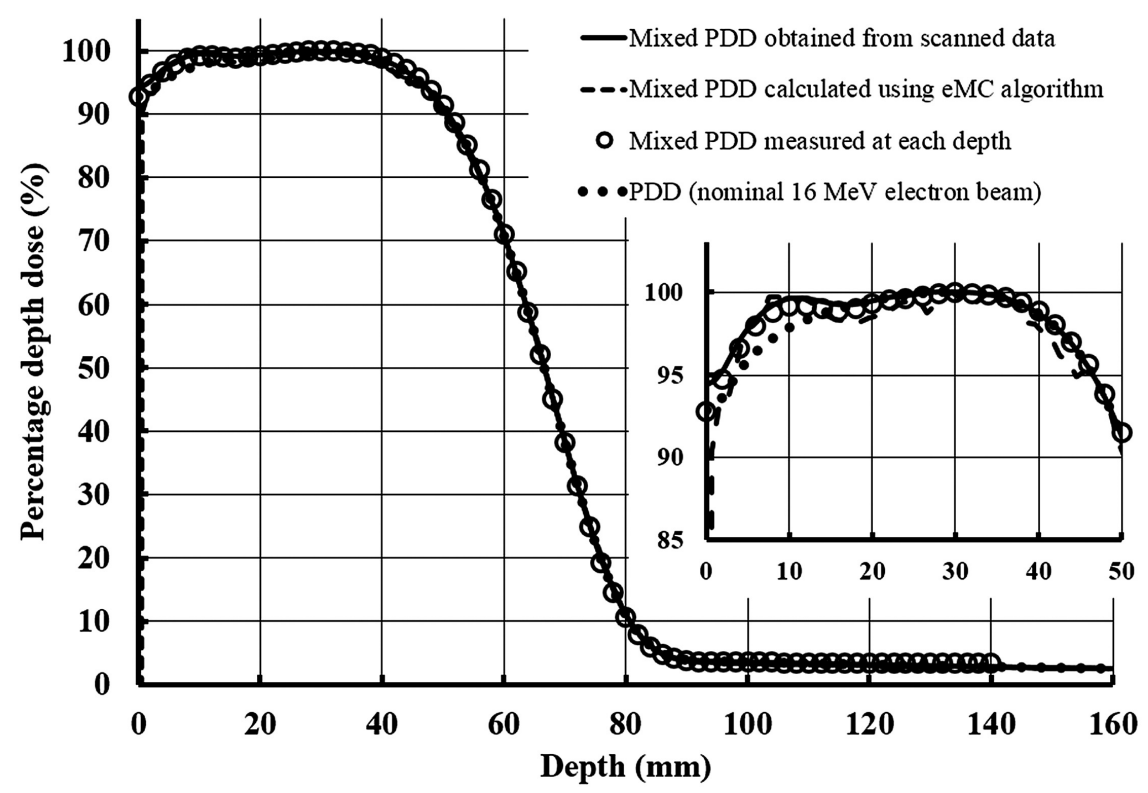

Fig. 6 Mixed PDD from the scanned data (solid line) and the distribution calculated using the eMC algorithm (dashed line) with weighting 2:98 from the $4 \mathrm{MeV}$ and $16 \mathrm{MeV}$ electron beams.

The dotted line represents the measured PDD for the nominal $16 \mathrm{MeV}$ electron beams.

The circles represent the measured PDD obtained from absorbed dose at each depth.

れぞれ示した。

\section{2-2ｅMC アルゴリズムを使用して計算された線量 分布}

Table 1〜3に太字で示された, 2-1 章で最適と判断 された組み合わせについて, e MCアルゴリズムを用 いて線量計算を行った. Figure 7〜9に eMCで計算
された線量分布を数值解析ソフトウェアの contour 表 示機能を使用して示す。 $\mathrm{eMC}$ で計算された異なる電 子ビームの組み合わせの線量分布は, Excel で計算さ れた值と比較して, 深さ $0.5 \mathrm{~mm}$ から線量深さの $90 \%$ まで $\pm 1.5 \%$ 以内で一致した。また， $R_{50} も \pm 0.5 \mathrm{~mm}$ 以 内で一致した。 

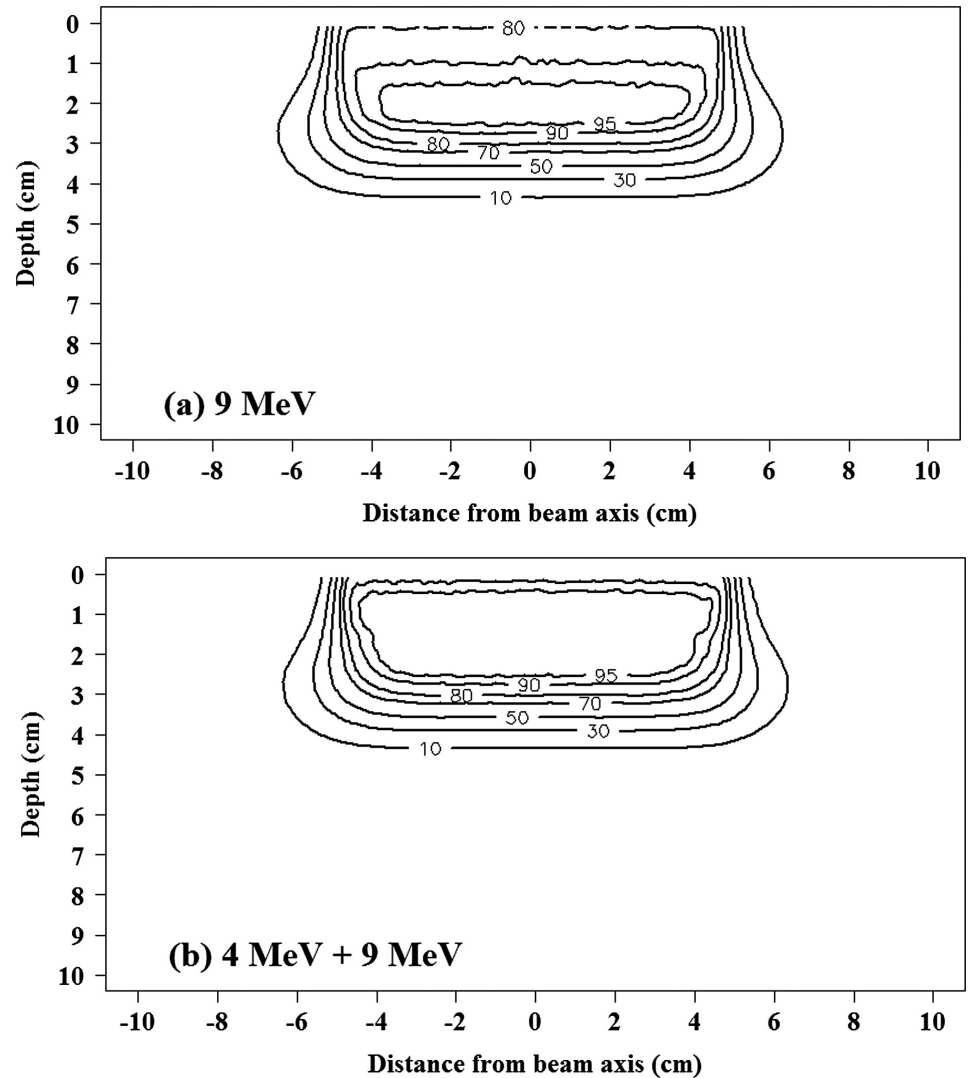

Fig. 7 Distributions calculated using the eMC algorithm for (a) the nominal $9 \mathrm{MeV}$ electron beam and (b) the mixed distribution with weighting 9:91 from the $4 \mathrm{MeV}$ and $9 \mathrm{MeV}$ electron beams.
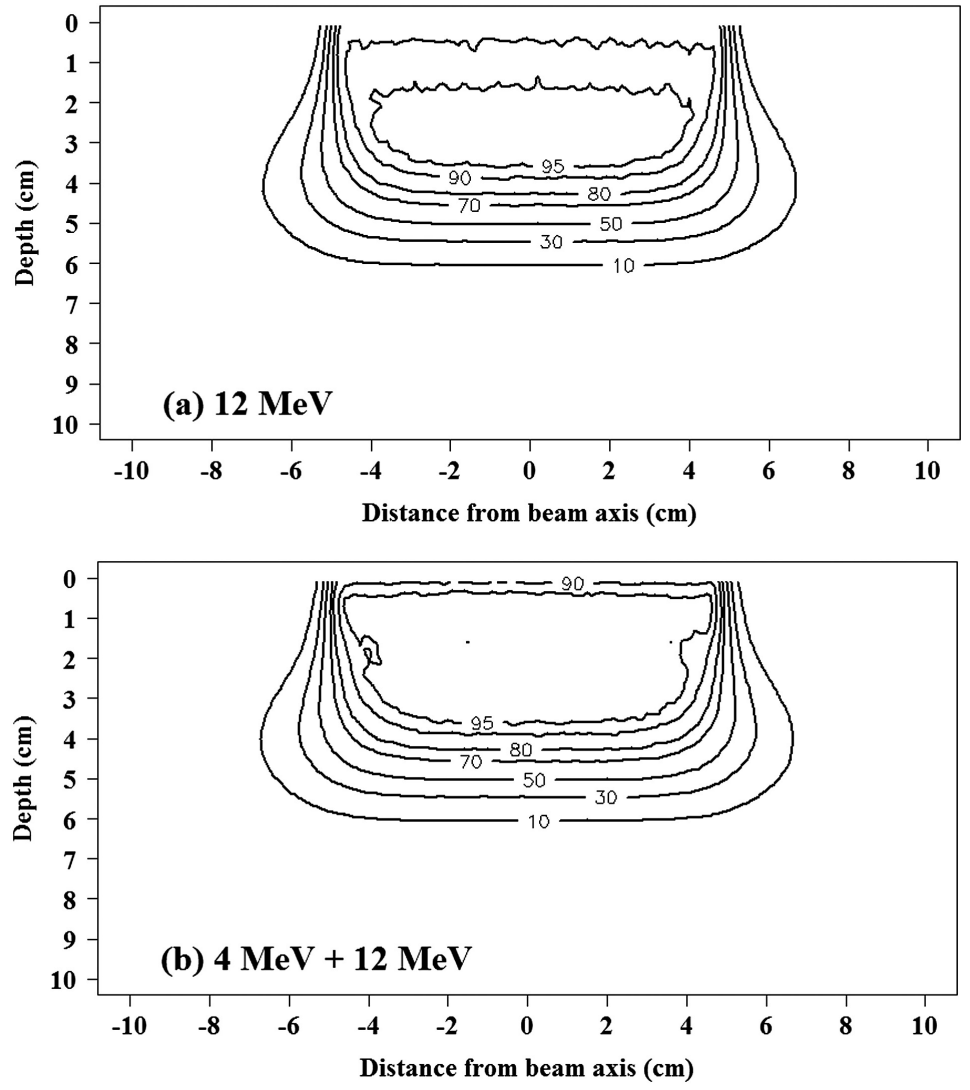

Fig. 8 Distributions calculated using the eMC algorithm for (a) the nominal $12 \mathrm{MeV}$ electron beam and (b) the mixed distribution with weighting 6:94 from the $4 \mathrm{MeV}$ and $12 \mathrm{MeV}$ electron beams. 

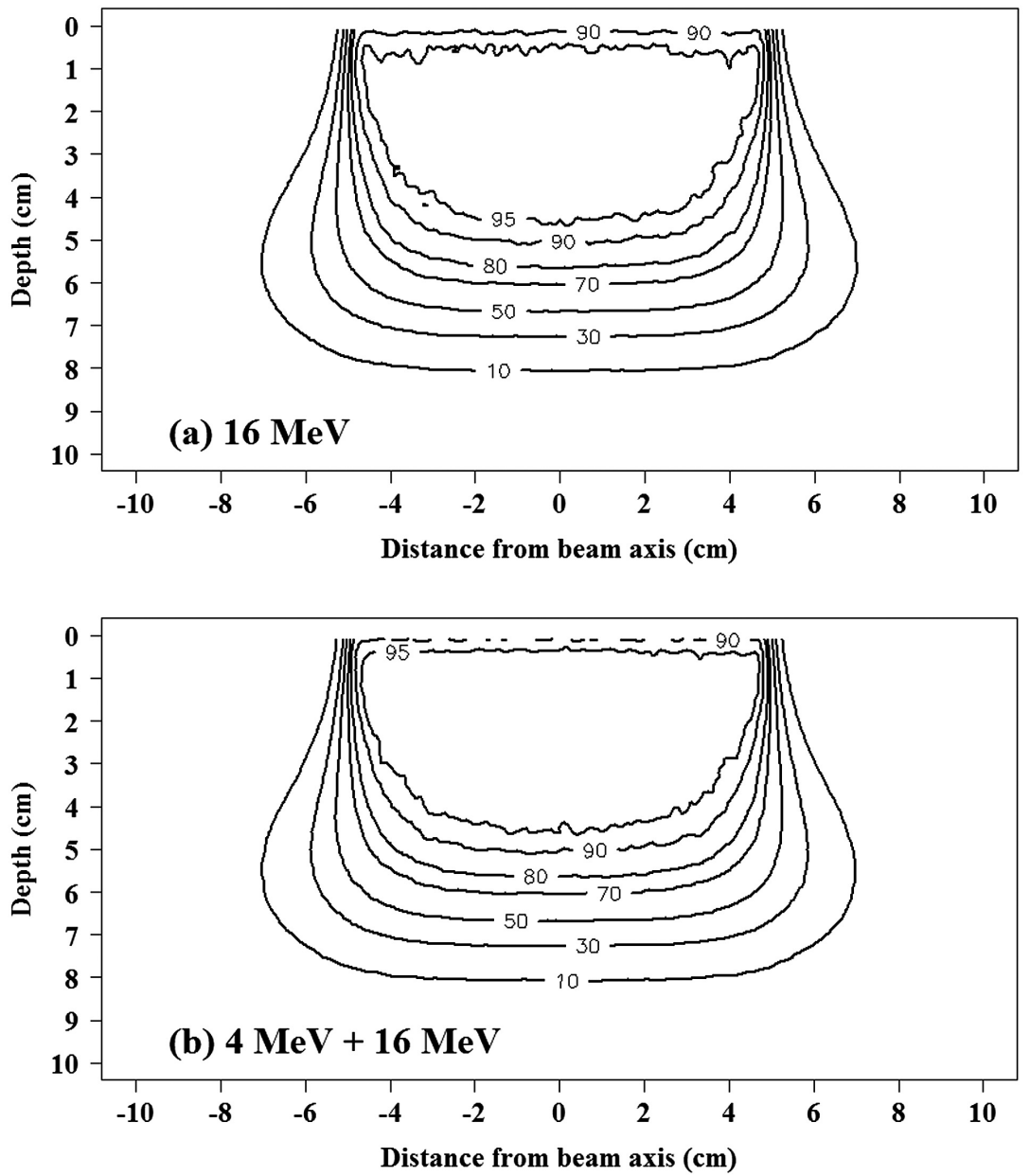

Fig. 9 Distributions calculated using the eMC algorithm for (a) the nominal $16 \mathrm{MeV}$ electron beam and (b) the mixed distribution with weighting 2:98 from the $4 \mathrm{MeV}$ and $16 \mathrm{MeV}$ electron beams.

\section{3. 考 察}

$9 \mathrm{MeV}$ および $12 \mathrm{MeV}$ 電子線を主体とした組み合 わせでは, $9 \mathrm{MeV}$ および $12 \mathrm{MeV}$ と大きく公称エネル ギーが異なる $4 \mathrm{MeV}$ を組み合わせることで, $\mathrm{d}_{\max }$ や $\mathrm{R}_{50}$ は, 主体となる電子線と一致させつつ, 深さ方向の 有効治療域幅を増加させることが可能であった。一 方，公称エネルギーが近い $6 \mathrm{MeV}$ や $9 \mathrm{MeV}$ 電子線と の組み合わせでは，治療域幅拡大への効果は小さく なった。これらの結果は, e $\mathrm{MC}$ アルゴリズムによる 線量計算でもみられる。低エネルギー電子線によっ て, 照射野内のビーム軸外についても, 浅部領域の線 量増加に寄与していることも確認された。

$12 \mathrm{MeV}$ の混合 PDD について, 本調査では, $d_{\max }$ や $\mathrm{R}_{50}$ の一致度や, $\mathrm{TR}$ の拡大率への効果から $4 \mathrm{MeV}$ と $12 \mathrm{MeV}$ の組み合わせが最適と判断された。 $12 \mathrm{MeV}$ 電子線ビームの場合も, $9 \mathrm{MeV}$ 電子線ビームと同様 に, $6 \mathrm{MeV}$ や $9 \mathrm{MeV}$ を組み合わせることによる, TR 拡大への効果は少なかった。 e MC アルゴリズムの線 量計算では, 深い領域への寄与はほとんどないが, 浅
い領域について側方への線量増加へも寄与しているこ とがわかる。

$16 \mathrm{MeV}$ を主体とした組み合わせでは，公称エネル ギー $16 \mathrm{MeV}$ の電子線が高い皮膚線量をもつため, 低 いエネルギーの電子線ビームとの組み合わせの効果は 小さかった。 Table 1３の結果は治療装置の種類, 照 射野，SSD などによって異なるため，ユーザは組み合 わせを選択する前に公称エネルギー電子ビームのデー 夕を取得する必要がある。

この研究では, 高エネルギー電子線に, 低いエネル ギーの電子線が, 非常に少ない割合で組み合わされて いるため, Das ${ }^{24)} や$, Wang $~^{25)}$ が報告している低 $\mathrm{MU}$ 值で生じる出力変動や平坦度㧍よび対称性の変動 から，計算された組み合わされた分布と実際に照射さ れる分布が異なる可能性がある。 これらの特性は, 電 子線エネルギーや治療装置によっても異なり, 各施設 での確認が必要となる。また, 本研究で使用した電子 線ビームの PDD は TPS に登録されているビーム データに基づいており, 日々の出力変動を考慮してい 
ないため ${ }^{26)}$, 日々の照射では正確に再現できない可能 性がある。

しかしながら, 本研究で使用した直線加速器 Clinac iX (Varian Medical Systems)では，2MU 以上におけ る $\mathrm{MU}$ と線量の直線性の変動は, $4 \mathrm{MeV}$ 電子線につ

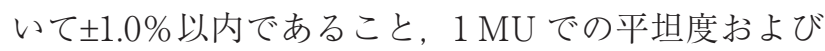
対称性の変動は $\pm 1.5 \%$ 以内であること, 日々の出力変 動は, $\pm 1 \%$ 以内であることが確認されている.よっ て，それぞれの電子線の割合が $2 \mathrm{MU}$ 以上である電子 線の組み合わせでは, Excel で計算された分布と実際 に照射される分布には大きな差はないと考えられる。

一方, $1 \mathrm{MU}$ では, $4 \mathrm{MeV}$ 電子線において，4.0\%程度 の差を生じることが確認されている。よって, それぞ れの電子線の割合が $1 \mathrm{MU}$ である電子線の組み合わせ では, Excel で計算された分布と実際に照射される分 布で大きな差が生じることが考えられる。本研究で最 適と判断された組み合わせにおいて, $4 \mathrm{MeV}$ 電子線に ついては，2MU 以上で検討できたことから低 MU 值 照射における出力特性の影響は少ないと考えられる.

一般に電子線線量分布は, 実用飛程付近で側方への広 がりが大きくなる。これは，電子線が物質に衝突した 際の多重散乱によるものであり，低エネルギーほど大 きい. このことから, 元の高エネルギー電子線分布 に, 低エネルギー電子線が混合された場合, 浅い領域 での側方への線量増加が懸念されるが, 重み付けの割 合からもわかるように，低エネルギー電子線成分の線 量の割合が非常に小さいため, 混合された電子線分布 にはほとんど現れない. 追加された低エネルギー電子 ビームの重みが小さい場合, それらは組み合わされた 線量分布にほとんど影響を及ほさないと考えられる。

また，電子線の分布は，照射野 ${ }^{17,27)}$, アプリケータの
種類 $^{28)}$ ，およびインサートブロック材料 ${ }^{29-31)}$ によって 変わることが報告されている。線量分布は皮膚表面へ の入射角によっても変化することが報告されてい る ${ }^{32)}$. 加えて, 治療装置に付属する照射筒やブロック 材料などは, 製造メーカによって異なる. 電子線線量 分布も異なることになる。本研究では, Clinac iX (Varian 社) から出力される電子線ビームについて評 価を行ったが, 他メーカで製造された治療装置を使用 する場合は, 同様の検討が必要である。また, TPSに よる線量計算は，小照射野などの線量分布計算值が, 測定值と計算值が一致していることを確認が必要で ある。

\section{4. 結 語}

本研究では, 複数のエネルギーの電子ビームを同じ 照射野に照射することにより, 外部電子放射線療法に おける治療範囲を拡大することの実現可能性について 検討した。この方法は, 電子ビーム分布の減衰特性を 維持しながら治療領域の深さを拡大することができる ので有用である。TPS を使用して計算された線量分 布は，スプレッドシートで計算された值と比較して， 差は少なかった。この結果は, 本研究での方法が臨床 的に適用可能であることを示唆している。一方で, 治 療装置特有の低 MU 值特性および日々の出力線量の 変動の影響を考慮する必要があり, 自施設の治療装置 の特性を,十分に理解したうえでの使用が要求される。

\section{利益相反}

筆頭著者および共著者全員が開示すべき利益相反は ない.

\section{参考文献}

1) Opp D, Forster K, Li W, et al. Evaluation of bolus electron conformal therapy compared with conventional techniques for the treatment of left chest wall postmastectomy in patients with breast cancer. Med Dosim 2013; 38(4): 448-453.

2) Tandberg DJ, Craciunescu O, Kelsey CR. Radiation therapy for cutaneous T-Cell lymphomas. Dermatol Clin 2015; 33(4): 703713.

3) Cheraghi N, Cognetta A Jr, Goldberg D. Radiation therapy for the adjunctive treatment of surgically excised Keroids: A review. J Clin Aesthet Dermatol 2017; 10(8): 12-15.

4) Khan FM, Gibbons JP. Khan's the physics of radiation therapy. 5th ed. Part II Classical Radiation Therapy. Lippincott Williams \& Wilkins, Philadelphia, PA, 2014; 256-308.

5) 日本放射線腫瘍学会, 日本放射線腫瘍学研究機構編. 各 論 1 皮膚の悪性腫瘍. 臨床放射線腫瘍学. 南江堂, 東京, 2012: 196-200.
6）熊谷孝三. 7.2 線量評価 放射線技術学シリーズ。放射 線治療技術学改訂 2 版. 日本放射線技術学会監修. オーム社, 東京, 2016: 126-141.

7) ICRU report 29, ICRU. 3. Recommendation for reporting absorbed doses in external beam therapy. Dose specification for reporting external beam therapy with photons and electrons. International Commission on Radiation Units and Measurements, Bethesda, MA, 1978; 10-16.

8) Jansson T, Lindman H, Nygard K, et al. Radiotherapy of breast cancer after breast-conserving surgery: an improved technique using mixed electron-photon beams with a multileaf collimator. Radioth Oncol 1998; 46(1): 83-89.

9) Khaledi N, Arbabi A, Sardari D, et al. Simultaneous production of mixed electron--photon beam in a medical LINAC: A feasibility study. Phys Med 2015; 31(4): 391-397.

10) Mueller S, Fix MK, Joosten A, et al. Simultaneous optimization 
of photons and electrons for mixed beam radiotherapy. Phys Med Biol 2017; 62(14): 5840-5860.

11) $\mathrm{Mu} \mathrm{X}$, Olofsson $\mathrm{L}$, Karlsson $M$, et al. Can photon IMRT be improved by combination with mixed electron and photon techniques? Acta Oncol 2004; 43(8): 727-735.

12) Ge Y, Faddegon BA. Study of intensity-modulated photonelectron radiation therapy using digital phantoms. Phys Med Biol 2011; 56(20): 6693-6708.

13) Salguero FJ, Arráns R, Palma BA, et al. Intensity- and energymodulated electron radiotherapy by means of an xMLC for head and neck shallow tumors. Phys Med Biol 2010; 55(5): 1413-1427.

14) Olofsson $\mathrm{L}, \mathrm{Mu} \mathrm{X}, \mathrm{Nill} \mathrm{S}$, et al. Intensity modulated radiation therapy with electrons using algorithm based energy/range selection methods. Radiat Oncol 2004; 73(2): 223-231.

15) Gentry JR, Steeves R, Paliwal BA. Inverse planning of energymodulated electron beams in radiotherapy. Med Dosim 2006; 31(4): 259-268.

16) Hu YA, Song H, Chen $\mathrm{Z}$, et al. Evaluation of an electron Monte Carlo dose calculation algorithm for electron beams. J Appl Clin Med Phys 2008; 9(3): 2720.

17) $\mathrm{Xu} \mathrm{Z}$, Walsh SE, Telivala TP, et al. Evaluation of the eclipse electron Monte Carlo dose calculation for small fields. J Appl Clin Med Phys 2009; 10(3): 2834.

18) Fix MK, Frei D, Volken W, et al. Monte Carlo dose calculation improvements for low energy electron beams using eMC. Phys Med Biol 2010; 55(16): 4577-4588.

19) Das IJ, Cheng CW, Watts RJ, et al. Accelerator beam data commissioning equipment and procedures: report of the TG106 of the Therapy Physics Committee of the AAPM. Med Phys 2008; 35(9): 4186-4215.

20) Khan FM, Doppke KP, Hogstrom KR, et al. Clinical electronbeam dosimetry: report of AAPM Radiation Therapy Committee Task Group No. 25. Med Phys 1991; 18(1): 73-109.

21）日本医学物理学会編. 外部放射線治療における水吸収線 量の標準計測法一標準計測法 12. 東京：通商産業研究社,
2012.

22) Araki F. Monte Carlo calculations of correction factors for plane-parallel ionization chambers in clinical electron dosimetry. Med Phys 2008; 35(9): 4033-4040.

23) ICRU Report No. 35. ICRU Radiation Dosimetry. Electron beams with energies between 1 and $50 \mathrm{MeV}$. Bethesda, MA: International Commission on Radiation Units and Measurements, 1984.

24) Das IJ, Harrington JC, Akber SF, et al. Dosimetric problems at low monitor unit settings for scanned and scattering foil electron beams. Med Phys 1994; 21(6): 821-826.

25) Wang Y, Heaton R, Norrlinger B, et al. Quality assurance of electron beams using a Varian electronic portal imaging device. Phys Med Biol 2013; 58(16): 5461-5475.

26) Beck JA, Budgell GJ, Roberts DA, et al. Electron beam quality control using an amorphous silicon EPID. Med Phys 2009; 36 (5): 1859-1866.

27) Dieterich S, Ford E, Pavord D, et al. Practical radiation oncology physics: A comparison to Gunderson \& Tepper's clinical radiation oncology. Elsevier, Amsterdam, 2016; 207-220.

28) Klein EE, Low DA, Purdy JA. Changes in electron beam dosimetry with a new scattering foil-applicator system on a CL2100C. Int J Radiat Oncol Biol Phys 1995; 32(2): 483-490.

29) Okumura $Y$, Mori $T$, Kitagawa $T$. Modification of dose distribution in high-energy electron beam treatment. Radiology 1971; 99(3): 683-686.

30) Ulin K, Palisca M. The use of scattering foil compensators in electron beam therapy. Int J Radiat Oncol Biol Phys 1996; 35 (4): 785-792.

31) Rusk BD, Carver RL, Gibbons JP, et al. A dosimetric comparison of copper and Cerrobend electron inserts. J Appl Clin Med Phys 2016; 17(5): 245-261.

32) Ekstrand KE, Dixon RL. The problem of obliquely incident beams in electron-beam treatment planning. Med Phys 1982; 9 (2): $276-278$, 